\title{
CAPITAL EXPENDITURE, LEVERAGE, GOOD CORPORATE GOVERNANCE, CORPORATE SOCIAL RESPONSIBILITY: PENGARUHNYA TERHADAP NILAI PERUSAHAAN
}

\author{
Noni Aisyah Sofiamira \\ Fakultas Ekonomi, Universitas Negeri Surabaya \\ Nadia Asandimitra \\ Fakultas Ekonomi, Universitas Negeri Surabaya \\ nadiaharyono@unesa.ac.id
}

\begin{abstract}
This study aims to investigate the effects of capital expenditure, leverage, managerial ownership, institutional ownership, and corporate social responsibility on firm value. We use Tobin's $Q$ as the proxy of firm value. Our sample firms are 11 mining firms listed in the Indonesian Stock Exchange for years 2011-2014. We generate our date from the official website of the Indonesian Stock Exchange. We run the multiple linear regression to analyze our data statistically. The results show that all independent variables simultaneously affect corporate value. Individual results indicate that managerial ownership (leverage) positively (negatively) affects firm value. However, other independent variables (institutional ownership and CSR) exhibit no significant influence on firm value.
\end{abstract}

Keywords: firm's value, Tobin's $Q$, capital expenditure, leverage, managerial ownership, institutional ownership, corporate social responsibility.

\begin{abstract}
ABSTRAK
Penelitian ini bertujuan untuk menganalisis pengaruh capital expenditure, leverage, kepemilikan manajerial, kepemilikan institusional, dan Corporate Social Responsibility terhadap nilai perusahaan yang diproksikan dengan Tobin's Q pada perusahaan sektor pertambangan yang terdaftar di BEI periode 2011-2014. Penelitian ini menggunakan data sekunder yang diperoleh dari website resmi BEI. Pengamatan dilakukan terhadap 11 perusahaan sebagai sampel yang didapat dari teknik purposive sampling. Hasil penelitian secara simultan seluruh variabel independen berpengaruh terhadap nilai perusahaan. Hasil secara parsial menunjukkan bahwa variabel leverage berpengaruh negatif terhadap nilai perusahaan, kepemilikan manajerial berpengaruh positif terhadap nilai perusahaan, sedangkan kepemilikan institusional dan CSR tidak berpengaruh terhadap nilai perusahaan.
\end{abstract}

Kata Kunci: nilai perusahaan, Tobin's $Q$, capital expenditure, leverage, kepemilikan manajerial, kepemilikan institusional, CSR. 


\section{PENDAHULUAN}

Indonesia merupakan satu dari beberapa negara berkembang di dunia ini, terbukti dengan semakin membaiknya perekonomian Indonesia yang menyebabkan timbulnya gairah bagi para pengusaha untuk mengelola perusahaannya di Indonesia (Pertiwi dan Pratama 2012). Perusahaan-perusahaan tersebut dituntut untuk turut memperhatikan value for money dalam menjalankan aktivitas bisnisnya. Kinerja perusahaan yang baik tak luput dari pengelolaannya yang baik pula, dimana harus sesuai dengan konsep 3E. Tiga elemen tersebut terdiri dari ekonomi, efisiensi, dan efektivitas. Ekonomi terkait dengan bagaimana upaya organisasi untuk menghindari pemborosan dalam memperoleh sumber daya. Efisiensi terkait akan produktivitas, yaitu apabila menghasilkan suatu output tertentu dengan input serendah-rendahnya maka dapat dikatakan efisien, begitu pula sebaliknya. Sedangkan efektivitas berhubungan dengan hasil yang diharapkan dan hasil yang telah dicapai. Tiga elemen utama yang digunakan sebagai dasaran dalam prinsip pengelolaan organisasi, atau yang biasa disebut value for money (Mardiasmo 2009). Dengan terpenuhinya value for money suatu perusahaan, maka dapat disimpulkan bahwa kinerja dari perusahaan tersebut baik sehingga dengan demikian akan tercapai pula tujuan dari perusahaan, yaitu nilai perusahaan.

Kusumajaya (2003) berasumsi bahwa nilai perusahaan ialah suatu hal yang penting sekali bagi perusahaan dikarenakan nilai tersebut mampu merefleksikan kinerja keseluruhan perusahaan sehingga mampu mempengaruhi pandangan investor akan perusahaan. Nilai perusahaan yang tinggi menggambarkan semakin sejahtera pemilik perusahaan.

Salah satu rasio keuangan yang biasa digunakan dalam mengukur nilai perusahaan yaitu Tobin's Q. Menurut Lindenberg dan Ross (1981), Tobin's Q merupakan penjumlahan nilai pasar ekuitas dengan total kewajiban yang kemudian dibagi dengan total aset. Sudiyatno dan Puspitasari (2010) menyatakan bahwa kondisi pasar yang bagus memiliki potensi yang dapat membuat harga pasar saham meningkat, demikian sebaliknya. Kondisi pasar dianggap memiliki potensi yang sangat besar dalam mempengaruhi tinggi rendahnya nilai Tobin's Q.

Berikut perhitungan rasio Q pada seluruh sektor perusahaan yang tercantum di Bursa Efek Indonesia selama tahun 2011-2014. 


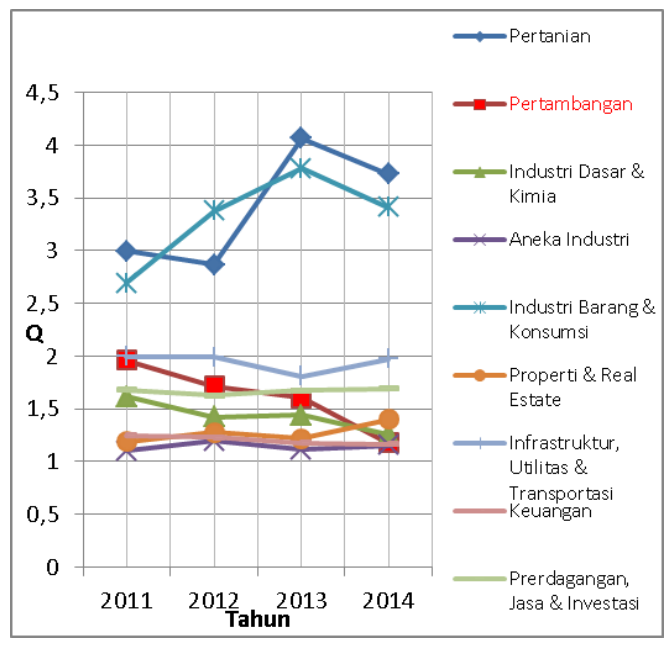

Grafik 1

Fluktuasi Tobin's Q Seluruh Sektor Perusahaan tahun 2011-2014

Grafik 1 menunjukkan bahwa perusahaan pertambangan merupakan satusatunya sektor yang terus mengalami penurunan nilai Q, dibanding sektor-sektor lain yang mengalami fluktuasi. Hal ini dikarenakan industri pertambangan di Indonesia mengalami penurunan pertumbuhan usaha. Beragam faktor menjadi penyebabnya salah satunya yaitu krisis perekonomian global yang semakin akut. Krisis tersebut dimulai dari krisis finansial di Eropa, tepatnya negara-negara lapisan pertama dalam kawasan Euro (Euro Zone) yakni Portugal, Irlandia, dan Yunani mengalami defisit dalam anggaran pemerintahannya yang dibarengi juga dengan peningkatan rasio hutang per PDB (Produk Domestik Bruto) dan berakibat pada penurunan kemampuan pembiayaan defisit (Fahadayna 2011).

Eropa merupakan salah satu konsumen batu bara terbesar di Indonesia, sehingga Indonesia pun tak lepas terkena imbasnya. Adanya krisis global membuat harga batu bara dunia menurun, dan permintaan Eropa akan batu bara impor dari Indonesia turut berkurang. Hal tersebut membuat persediaan batu bara Indonesia menumpuk banyak dikarenakan permintaan yang menurun, sehingga harga batu bara pun menurun. Tidak sedikit perusahaan tambang yang terpaksa bankrut lantaran imbas kondisi tersebut. Dikutip dari Kompas.com pada 12 Agustus 2015 (Sucipto 2015), sebanyak kurang-lebih 125 perusahaan pertambangan batu bara di Kalimantan Timur tidak beroperasi. Oleh karena itu sektor pertambangan dipilih sebagai objek penelitian.

Sudiyatno, Puspitasari, dan Kartika (2012) menyatakan bahwa dunia bisnis akan selalu membutuhkan manajemen untuk berkreasi dalam upaya pengembangan kinerjanya. Manajemen sudah seharusnya mempunyai kemampuan untuk mengambil manfaat dari semua peluang yang ada untuk mengelola perusahaan dalam rangka mengembangkan kinerja perusahaan. Salah satu pengelolaan perusahaan yang perlu diperhatikan yaitu termasuk masalah keuangan. Namun menurut kinerja keuangan tak lagi memadai dalam mengukur keseluruhan kinerja manajemen dikarenakan adanya 
perubahan dunia bisnis, sehingga diperlukan pula pertimbangan nonfinansial. Kinerja keuangan dapat dilihat dari keputusan investasi dan keputusan pendanaan suatu perusahaan. Sedangkan kinerja nonkeuangan dapat dilihat dari pelaksanaan Good Corporate Governance (GCG) dan Corporate Social Responsibility (CSR) pada perusahaan tersebut.

Bentuk keputusan investasi pada penelitian ini yaitu capital expenditure atau pengeluaran modal, yang tepatnya merupakan investasi yang dilakukan pada aktiva tetap. Elmasr (2007) menyatakan bahwa perusahaan membutuhkan investasi barang modal untuk melakukan aktivitas operasional sehari-hari dan menghasilkan manfaat jangka panjang. Investasi tersebut dapat berupa aset nyata seperti mesin, pabrik, peralatan, dan aset berwujud lainnya. Motif dasar dari pengeluaran modal yaitu untuk penggantian, ekspansi, dan atau memperbaharui aktiva tetap atau mencari manfaat yang memungkinkan untuk less tangible dalam jangka panjang.

Penelitian tentang capital expenditure sebelumnya pernah dilakukan oleh Sudiyatno, Puspitasari, dan Kartika (2012), dan Nguyen (2015). Kedua penelitian tersebut menyatakan bahwa rasio CAPEX tidak berpengaruh terhadap Tobin's Q. Sebaliknya, penelitian dari Haryono et al. (2015) mendapatkan hasil yaitu pengeluaran modal memiliki pengaruh yang signifikan dengan arah positif terhadap nilai perusahaan.

Struktur modal ialah salah satu bentuk keputusan pendanaan. Ogolmagai (2013) menyatakan bahwa struktur modal merupakan struktur pembiayaan. Struktur pembiayaan dapat berasal dari dalam maupun luar perusahaan. Struktur pembiayaan yang berasal dari eksternal perusahaan yaitu hutang. Penggunaan hutang harus hatihati oleh pihak manajemen. Hermuningsih (2013) memberi temuan bahwa manajemen perusahaan cenderung melakukan lebih banyak hutang ketika mereka yakin akan prospek perusahaan yang bagus pada masa mendatang dan ingin meningkatkan harga saham. Hal tersebut dilakukan manajer sebagai suatu sinyal yang lebih dapat dipercaya oleh calon investor bahwa perusahaan sedang memiliki prospek yang bagus.

Ogolmagai (2013) meneliti pengaruh leverage terhadap nilai perusahaan pada perusahaan industri manufaktur periode 2008-2011 dimana hasilnya menyatakan bahwa leverage, baik dengan proksi DAR maupun DER tidak mempunyai pengaruh baik secara simultan dan parsial terhadap Tobin's Q. Sedangkan Haryono et al. (2015) menyatakan bahwa leverage memiliki pengaruh positif signifikan terhadap nilai perusahaan. Sebaliknya, Nguyen (2015) yang meneliti leverage dengan proksi DER menemukan pengaruh negatif signifikan terhadap Tobin's Q.

Pengeluaran dan penggunaan modal eksternal yang turut mempengaruhi nilai perusahaan tersebut pun rentan terhadap konflik antara stockholder dan manajemen, yang biasa kita kenal sebagai agency conflict. Agency conflict terjadi antara pemegang saham dan manajer yang kemudian menyebabkan timbulnya biaya agensi (agency cost). Salah satu cara agar hal tersebut berkurang yaitu dengan meningkatkan 
kepemilikan saham oleh manajerial (pihak internal). Menurut Jensen dan Meckling (1976), kebijakan perusahaan juga dapat dipengaruhi oleh proporsi kepemilikan saham yang dikendalikan oleh manajer.

Penelitian dari Susanto dan Subekti (2013) menemukan bahwa kepemilikan manajerial mempengaruhi Tobin's Q secara signifikan dengan arah positif. Hasil tersebut sesuai dengan hasil dari penelitian yang dilakukan oleh Rizqia et al. (2013) Sedangkan Siek dan Murhadi (2015) menemukan bahwa tidak ada pengaruh antara kepemilikan manajerial pada Tobin's Q dan hasil penelitian Agustine (2014) menyatakan bahwa proporsi kepemilikan saham oleh manajer memiliki pengaruh negatif yang signifikan terhadap Tobin's Q.

Faktor lainnya yang juga dapat mempengaruhi nilai perusahaan yaitu kepemilikan institusional. Tarjo (2008) menyatakan bahwa kepemilikan institusional ialah proporsi kepemilikan saham oleh lembaga-lembaga resmi, seperti perusahaan asuransi, yayasan, bank, dan lembaga lainnya. Adanya kepemilikan saham oleh investor institusi mampu mengontrol dan mengarahkan manajer dalam pembuatan kebijakan dan keputusan perusahaan sehingga kepemilikan institusional diasumsikan dapat mengurangi agency conflict (Haryono et al., 2015).

Haryono et al. (2015) menemukan hubungan positif signifikan mengenai pengaruh kepemilikan institusional terhadap Tobin's Q. Sebaliknya, Susanto dan Subekti (2013), Siek dan Murhadi (2015), Septianingrum (2014), dan Saputra (2010) tidak menemukan pengaruh antara kepemilikan institusional dengan nilai perusahaan.

Faktor yang tidak kalah pentingnya dalam mempengaruhi nilai pada suatu perusahaan, yaitu Corporate Social Responsibility (CSR). Saraswati (2012) menyatakan untuk menjaga nilai perusahaan agar tumbuh secara berkelanjutan tidak cukup hanya dengan mengandalkan kondisi keuangan saja. Kini dimensi sosial dan lingkungan hidup juga perlu diperhatikan untuk menjamin keberlanjutan perusahaan. Selain mengejar profit, perusahaan diharuskan untuk memberi perhatian lebih dalam pemenuhan kesejahteraan masyarakat, serta turut terlibat secara aktif dalam menjaga kelestarian alam sekitar.

Penelitian mengenai pengaruh $C S R$ terhadap nilai perusahaan telah beberapa kali dilakukan. Bidhari et al. (2013) menemukan pengaruh yang signifikan dengan arah koefisien positif antara CSR dengan nilai perusahaan. Hasil ini sejalan dengan penelitian yang dilakukan oleh Tjia dan Setiawati (2012); Rosiana et al. (2013); Amri dan Untara (2010) serta Agustina (2013). Di sisi lain, Susanto dan Subekti (2013); Yuliana dan Juniarti (2015); Rachman dan Maghviroh (2011); Septianingrum (2014) serta Agustine (2014), menyatakan bahwa tidak ada pengaruh yang ditemukan pada hubungan antara CSR terhadap nilai perusahaan. Hasil riset yang inkonklusif memotivasi dilakukan penelitian ini. Penelitian ini bermanfaat menjadi bahan masukan atau pertimbangan bagi perusahaan yang berkaitan dengan Capital Expenditure, Leverage, Good Corporate Governance, Corporate Social 
Responsibility, dalam upaya memaksimalkan kinerja perusahaan. Penelitian ini juga dapat digunakan sebagai dasar penentuan kebijaksanaan belanja modal, penerapan Corporate Social Responsibility, kebijakan pendanaan dan Good Corporate Governance suatu perusahaan agar dapat meningkatkan efisiensi dan pendapatan perusahaan

\section{KAJIAN PUSTAKA DAN PERUMUSAN HIPOTESIS}

\section{Signaling Theory}

Sinyal ialah tindakan perusahaan yang memberikan petunjuk atau aba-aba kepada para stakeholder mengenai bagaimana mereka memandang prospek perusahaan (Brigham dan Houston 2006). Signaling theory mengemukakan tentang bagaimana seharusnya sebuah perusahaan memberikan sinyal kepada pengguna laporan keuangan.

Sebuah perusahaan dengan prospek yang sangat menguntungkan akan mencoba untuk menghindari penjualan saham dan lebih memilih mendapatkan modal baru dengan cara-cara yang lain, termasuk menggunakan utang. Sedangkan perusahaan dengan prospek yang tidak menguntungkan akan ingin menjual saham, yang artinya menarik investor-investor baru untuk berbagi kerugian yang diperkirakan akan mereka alami. Oleh karena itu adanya pengumuman penawaran saham biasanya akan dianggap sebagai suatu sinyal bahwa prospek perusahaan seperti yang dilihat oleh manajemen tidak terlalu cerah (Brigham dan Houston 2006).

\section{Teori Trade-Off}

Pada penelitian yang dilakukan Ogolmagai (2013), teori trade-off menjelaskan bahwa peningkatan rasio hutang pada struktur modal akan meningkatkan nilai perusahaan. Begitupun dengan pendapat Kusumajaya (2003) yang menyebutkan bahwa teori trade-off dapat memprediksi hubungan positif antara struktur modal dengan nilai perusahaan dengan asumsi keuntungan pajak masih lebih besar dari biaya tekanan finansial dan biaya keagenan. Jika posisi struktur modal berada di bawah titik optimal maka setiap penambahan utang akan meningkatkan nilai perusahaan, tetapi setelah melewati titik optimal tersebut peningkatan penggunaan utang dapat menurunkan nilai perusahaan. Titik optimal dapat diperoleh dengan adanya keseimbangan antara keuntungan tax shield dengan financial distress dan agency cost, karena penggunaan leverage, atau terjadi trade-off antara benefit dengan cost (Myers 1977).

\section{Teori Keagenan}

Teori Keagenan merupakan rumusan permasalahan yang menjelaskan mengenai konflik antara pemilik perusahaan (principal) dengan pengelola perusahaan (agent) (Sisharini 2013). Jensen dan Meckling (1976) menyatakan bahwa dalam hubungan keagenan terdapat konflik kepentingan yang terjadi karena adanya 
perbedaan tujuan dari masing-masing pihak. Manajer yang merupakan pengelola perusahaan tentu memiliki kepentingan untuk memaksimalkan kesejahteraannya sendiri. Disisi lain, manajer juga memiliki kewajiban dalam menjalankan tugasnya untuk memaksimalkan kesejahteraan para pemilik perusahaan (principal) baik dalam jangka pendek maupun jangka panjang. Adanya perbedaan tujuan serta pemisahan antara kepemilikan dan pengelolaan perusahaan tersebut menyebabkan manajer dapat bertindak sesuai keinginan mereka sendiri tanpa memperhatikan kepentingan principal.

Sisharini (2013) menjelaskan bahwa tujuan pihak manajer perusahaan sering kali bertentangan dengan meningkatnya kemakmuran pemegang saham melalui peningkatan nilai perusahaan. Hal tersebut menimbulkan konflik kepentingan antara manajer dan pemegang saham. Untuk meminimalisir konflik kepentingan tersebut, perusahaan dapat melakukan suatu mekanisme pengawasan yang dapat mensejajarkan kepentingan-kepentingan terkait.

Munculnya mekanisme pengawasan tersebut dapat menimbulkan biaya, yang disebut sebagai agency cost (biaya keagenan). Ada beberapa alternatif untuk mengurangi agency cost, di antaranya yaitu penerapan Good Corporate Governance (Haruman 2008).

\section{Teori Legitimasi}

Kegiatan operasional perusahaan sangat mempengaruhi masyarakat sekitarnya. Eksistensi suatu perusahaan dapat diterima sebagai anggota masyarakat, namun sebaliknya eksistensinya pun dapat terancam apabila perusahaan tidak dapat menyesuaikan diri dengan aturan dan nilai-nilai dari masyarakat tersebut, atau bahkan merugikan lingkungan sekitar. Oleh karena itu, perusahaan mencoba untuk memperoleh kesesuaian antara tindakan organisasi dan nilai-nilai publik karena tindakan organisasi dan nilai-nilai masyarakat tersebut tidak selamanya selaras seperti yang diharapkan (Saraswati 2012).

Legitimasi merupakan keadaan psikologis keberpihakan orang dan kelompok orang yang sangat peka terhadap gejala lingkungan sekitarnya baik fisik maupun nonfisik (Hadi 2011). Legitimasi masyarakat merupakan faktor strategis bagi perusahaan untuk mengembangkan perusahaan dalam jangka panjang. O'Donovan (2002) berasumsi bahwa legitimasi merupakan sumber daya yang potensial bagi perusahaan untuk bertahan hidup dikarenakan legitimasi dipandang sebagai sesuatu yang diberikan masyarakat kepada perusahaan dan sesuatu yang diinginkan atau dicari perusahaan dari masyarakat.

Legitimasi dapat dikatakan sebagai sistem pengelolaan perusahaan yang berorientasi pada keberpihakan terhadap masyarakat, pemerintah individu dan kelompok masyarakat. Ketika ada perbedaan nilai-nilai yang dianut perusahaan dengan nilai-nilai masyarakat, legitimasi perusahaan berada pada posisi terancam. Legitimasi perusahaan dapat diperoleh dengan meningkatkan reputasi perusahaan 
untuk mendapatkan nilai positif dari masyarakat melalui tanggung jawab sosial perusahaan atau yang biasa disebut CSR (Saraswati 2012). Pengungkapan CSR dilakukan perusahaan untuk mendapatkan nilai positif dan legitimasi dari masyarakat.

\section{Identifikasi Faktor-Faktor yang Mempengaruhi Nilai Perusahaan}

\section{Capital Expenditure}

Perusahaan yang melakukan investasi modal cenderung dapat menarik para investor karena diharapkan keputusan-keputusan investasi tersebut akan membawa keuntungan lebih besar di masa yang akan datang (Brealey et al., 2007). Penggunaan capital expenditure sebagai keputusan investasi memberikan sinyal positif akan pertumbuhan perusahaan di masa mendatang yang kemudian direspon baik oleh para investor (Achmad dan Amanah 2014). Hal tersebut sesuai dengan signaling theory dimana keputusan investasi dapat memberikan sinyal positif bagi para investor. Hal ini dikarenakan dengan investasi tersebut para investor berharap bahwa pertumbuhan perusahaan di masa yang akan datang akan meningkat. Peningkatan pertumbuhan perusahaan mencerminkan kinerja perusahaan yang baik. Dengan begitu nilai perusahaan pun akan meningkat secara beriringan. Selain itu, pengeluaran modal juga dapat mengoptimalkan arus kas perusahaan. Dengan optimalnya arus kas tersebut maka kinerja perusahaan serta pertumbuhan perusahaan di masa mendatang pun juga meningkat. Kinerja perusahaan yang baik dan meningkat juga akan meningkatkan nilai perusahaan. Hipotesis satu pada penelitian ini diusulkan sebagai berikut:

H1: Capital Expenditure berpengaruh positif terhadap nilai perusahaan.

\section{Leverage}

Leverage merupakan kemampuan perusahaan untuk menggunakan hutang untuk memaksimalkan keuntungan (Rizqia et al., 2013). Sesuai dengan teori pensinyalan, penggunaan hutang sebagai keputusan pendanaan pada suatu perusahaan akan memberikan sinyal positif bagi para investor. Achmad dan Amanah (2014) menjelaskan bahwa penggunaan dana eksternal akan menambah pendapatan perusahaan yang nantinya akan digunakan untuk kegiatan investasi yang menguntungkan bagi perusahaan. Sehingga dengan begitu harapan para investor akan pertumbuhan perusahaan di masa mendatang akan naik dan nilai perusahaan pun meningkat.

Selain itu, penggunaan leverage cukup menguntungkan bagi perusahaan karena adanya efek dari corporate tax shield, dimana hutang dapat melindungi tingkat pajak perusahaan atas laba sehingga proporsi hutang pada perusahaan dapat optimal dan kinerja perusahaan pun dapat meningkat. Hal tersebut sesuai dengan teori tradeoff dimana penggunaan hutang akan meningkatkan nilai perusahaan sampai batas leverage tertentu (optimal), dan setelah melewati titik optimal, penggunaan leverage akan menimbulkan biaya kebangkrutan yang lebih besar sehingga dapat menurunkan 
nilai perusahaan (Myers 1977). Hipotesis dua pada penelitian ini diusulkan sebagai berikut:

H2: Leverage berpengaruh positif terhadap nilai perusahaan.

\section{Kepemilikan Manajerial}

Kepemilikan manajerial merupakan kepemilikan saham yang dimiliki oleh pihak manajemen seperti dewan direksi atau dewan komisaris. Manajer yang memiliki saham di perusahaannya akan termotivasi meningkatkan nilai pasar perusahaan. Sehingga hal ini dapat mengurangi biaya agensi dengan mensejajarkan kepentingan manajer dan pemegang saham (Brealey et al., 2007). Dikarenakan tindakan manajer yang memiliki saham perusahaan akan semakin produktif dalam pekerjaannya guna memaksimalkan nilai perusahaan, sehingga manajer pun akan mengungkapkan informasi sosial demi meningkatkan imej perusahaan. Oleh karena itu perusahaan dapat mengurangi konflik agensi dengan adanya prosentase kepemilikan manajerial yang tinggi (Agustine 2014). Berdasarkan argumentasi dan hasil riset terdahulu, hipotesis tiga diusulkan sebagai berikut.

H3: Kepemilikan manajerial berpengaruh positif terhadap nilai perusahaan.

\section{Kepemilikan Institusional}

Kepemilikan institusional ialah kepemilikan saham oleh lembaga-lembaga institusional. Kepemilikan institusi memiliki peranan penting dalam meminimalisir konflik keagenan. Keberadaan investor institusi dipandang mampu menjadi sebuah mekanisme pengawasan yang efektif dalam setiap decision making yang dilakukan oleh manajemen. Hal tersebut dikarenakan investor institusional tidak mudah percaya terhadap tindakan manipulasi laba (Jensen dan Meckling 1976). Perusahaan dengan kepemilikan institusional yang besar mengindikasikan kemampuannya untuk memonitor manajemen. Menurut Haryono et al. (2015) adanya monitoring yang efektif dari kepemilikan institusional terhadap manajer, dapat mendorong dan mendisiplinkan kinerja manajemen untuk meningkatkan kesejahteraan pemegang saham dan nilai perusahaan. Hipotesis empat pada penelitian ini diusulkan sebagai berikut.

H4: Kepemilikan institusional berpengaruh positif terhadap nilai perusahaan.

\section{Corporate Social Responsibility}

CSR didefinisikan sebagai program atau tindakan sosial yang muncul di luar kepentingan perusahaan (McWilliams dan Siegel 2000). CSR yang dilakukan oleh perusahaan dapat mengurangi risiko sosial dan dapat menguntungkan perusahaan 
dalam jangka panjang. Dengan pengungkapan tanggung jawab sosial, perusahaan berharap akan mendapatkan legitimasi sosial dan pemaksimalan ukuran keuangan dalam jangka panjang. Tidak hanya itu, pengungkapan tanggug jawab sosial perusahaan juga diharapkan dapat meningkatkan citra perusahaan serta meningkatkan penjualan. Perusahaan yang melakukan tanggung jawab sosial berharap akan mendapat respon positif oleh para pelaku pasar (Sayekti dan Ludovicus 2007). Apresiasi dan reaksi pasar yang positif tersebut menciptakan suatu kinerja pasar yang baik bagi perusahaan yang mengakibatkan harga saham tinggi dan perusahaan dengan mudah menarik dana baru. Hal tersebut memungkinkan perusahaan untuk berkembang dan menciptakan kondisi pasar yang sesuai, sehingga dapat meningkatkan kinerja pasar perusahaan, yang pada gilirannya akan menciptakan nilai perusahaan yang tinggi dan pertumbuhan yang berkelanjutan (Saputra 2010). Hipotesis lima pada penelitian ini diusulkan sebagai berikut:

H5: Corporate Social Responsibility berpengaruh positif terhadap nilai perusahaan.

\section{METODA PENELITIAN}

Jenis penelitian ini merupakan penelitian konklusif kausal yang bertujuan untuk mendapatkan bukti hubungan sebab akibat antara capital expenditure, leverage, kepemilikan manajerial, kepemilikan institusional, dan tanggung jawab sosial atau CSR terhadap nilai perusahaan pada perusahaan pertambangan yang listing di BEI selama tahun 2011-2014.

Penelitian ini menggunakan data penelitian kuantitatif dengan data laporan keuangan perusahaan sektor pertambangan periode 2011-2014. Sumber data penelitian yang digunakan ialah data sekunder karena diperoleh dari halaman daring Bursa Efek Indonesia (BEI) yaitu www.idx.co.id.

Populasi dalam penelitian ini ialah seluruh perusahaan sektor pertambangan yang listing di BEI selama tahun 2011-2014. Pengambilan sampel menggunakan teknik purposive sampling, yakni perusahaan sektor pertambangan yang terdaftar di Bursa Efek Indonesia dan mempublikasikan laporan tahunan lengkap selama berturutturut selama periode 2011-2014, serta yang memiliki kelengkapan data terkait dengan variabel-variabel yang digunakan dalam penelitian. Berdasarkan keterangan pemilihan sampel tersebut, diperoleh sampel sebanyak 12 perusahaan. Namun terdapat 1 perusahaan yang memiliki data outlier dan harus dikeluarkan dari sampel penelitian, sehingga sampel penelitian kemudian menjadi 11 perusahaan. Perioda penelitian selama empat tahun sehingga data yang digunakan sebanyak 44 data.

Teknik analisis data menggunakan regresi linear berganda yang bertujuan untuk mengetahui pengaruh dari variabel bebas terhadap variabel terikat (dependen). Sebelum dilakukan analisis regresi berganda, terlebih dahulu dilakukan uji asumsi 
klasik. Ketepatan fungsi regresi dalam menafsirkan nilai aktual dapat diukur dari nilai koefisien determinasi, nilai statistik F dan nilai statistik t (Ghozali 2013).

Variabel dalam penelitian ini terbagi menjadi variabel terikat dan variabel bebas. Variabel terikat (Y) dalam penelitian ini yaitu nilai perusahaan yang diproksikan dengan Tobin's Q. Rasio Tobin's Q merupakan rasio yang bukan hanya memasukkan unsur saham biasa maupun ekuitas perusahaan saja, namun juga memasukkan seluruh unsur hutang dan modal saham perusahaan, serta seluruh aset perusahaan. Hal tersebut dikarenakan sumber pembiayaan operasional perusahaan yang tidak hanya berasal dari ekuitas saja, namun juga dari hutang yang diberikan oleh kreditur. Dengan memasukkan seluruh aset perusahaan dalam perhitungan, Tobin's Q membuat perusahaan tidak hanya terfokus pada satu tipe investor saja, seperti investor dalam bentuk saham, namun juga bagi kreditur (Sukamulja 2004). Oleh karena itu rasio ini disebut-sebut sebagai rasio yang dapat memberikan informasi yang paling baik. Rasio Tobin's Q dapat dihitung dengan menggunakan rumus:

Tobin's $Q=\frac{M V E+D E B T}{T A}$ 1

Variabel independen yang digunakkan pada penelitian ini meliputi Capital Expenditure (X1), Leverage (X2), Kepemilikan Manajerial (X3), Kepemilikan Institusional (X4), dan Corporate Social Responsibility (X5).

\section{Capital Expenditure}

Capital expenditure merupakan suatu biaya yang harus dikeluarkan perusahaan untuk memperoleh ataupun memperpanjang masa manfaat dari suatu aset yang memiliki manfaat jangka panjang, yaitu aset tetap seperti tanah, bangunan, dan mesin produksi (Carter dan Usry 2002). Pada penelitian ini capital expenditure dihitung dengan menggunakan rasio CAPEX yang didapat dari prosentase perbandingan nilai total fixed asset tahun ini dengan total fixed asset pada tahun sebelumnya yang tercantum pada laporan tahunan perusahaan seperti yang dijelaskan oleh Griner dan Gordon (1995), Sartono (2001), dan Hamidi (2003) dengan rumus sebagai berikut:

$\operatorname{CAPEX}_{t}=\triangle F A_{t}$

\section{Leverage}

Besar kecilnya rasio hutang dapat dilihat pada rasio Debt Equity Ratio (DER). Rasio DER dapat diketahui melalui perbandingan dari total hutang dengan total ekuitas yang tercantum pada laporan keuangan maupun laporan tahunan perusahaan. Menurut Ogolmagai (2013) DER menggunakan rumus sebagai berikut:

$\mathrm{DER}=\frac{\text { Total Hutang }}{\text { Total Ekuitas }} \times 100 \%$ 


\section{Kepemilikan Manajerial}

Kepemilikan manajemen ialah proporsi kepemilikan saham oleh pihak manajemen perusahaan yang mempunyai peran dalam pembuatan keputusan dari perusahaan tersebut, misalnya saja seperti direktur dan komisaris (Diyah dan Erman 2009). Oleh karena itu kepemilikan manajerial pada penelitian ini diukur menggunakan prosentase kepemilikan saham yang dimiliki manajemen perusahaan seperti dewan direksi dan dewan komisaris kemudian dibagi dengan jumlah saham yang beredar. Menurut Rizqia et al. (2013) rumus kepemilikan manajerial dapat ditulis sebagai berikut:

$M O W N=\frac{\sum \text { Saham yang dimiliki oleh dewan direksi dan komisaris }}{\sum \text { Saham yang beredar }} \times 100 \%$ 4

\section{Corporate Social Responsibility}

Konsep pelaporan CSR digagas dalam Global Reporting Inisiative (GRI). Berdasarkan GRI Guidelines, perusahaan diwajibkan untuk menjelaskan dampak dari kegiatan perusahaan terhadap 3 dimensi, yaitu ekonomi, lingkungan dan sosial pada bagian standard disclosures. Dimensi tersebut kemudian diperluas menjadi 7 dimensi, yaitu ekonomi, sosial, lingkungan, praktek tenaga kerja, hak asasi manusia, masyarakat, dan tanggungjawab produk, yang mana didalamnya terdiri dari 79 rincian penjelasan item (Agustine 2014). CSR dapat diukur dengan melihat 79 daftar pengungkapan CSR perusahaan, yang tercantum secara langsung dan tidak langsung baik pada laporan keuangan maupun laporan sustainability yang dikeluarkan oleh perusahaan. Sembiring (2003) menyatakan bahwa pengukuran CSR perusahaan dilakukan dengan perhitungan dummy. Perhitungan dummy dilakukan dengan memberi skor "0" untuk setiap item yang tidak diungkapkan dalam laporan dan memberi skor " 1 " untuk setiap item yang diungkapkan. Keseluruhan poin tersebut kemudian di rata-rata dan dipresentasekan. Menurut Rosiana et al. (2013), perhitungan tersebut dapat dirumuskan sebagai berikut: $\operatorname{CSRI}_{j}=\frac{n}{k} \times 100 \%$ 5

\section{ANALISIS DAN PEMBAHASAN}

Data dalam penelitian ini meliputi nilai perusahaan (Q) sebagai variabel dependen dan capital expenditure (CAPEX), leverage (LEV), kepemilikan manajerial (MOWN), kepemilikan institusional (INST), dan Corporate Social Responsibility $(C S R)$ sebagai variabel independen. Adapun deskripsi data penelitiannya tersaji pada tabel di bawah ini.

Tabel 1

Statistik Deskriptif $(\mathrm{N}=44)$

\begin{tabular}{ccccc}
\hline & Minimum & Maximum & Mean & Std. Deviation \\
\hline $\mathbf{Q}$ & 0,73 & 6,92 & 1,9374 & 1,26738 \\
CAPEX & -241.472 .360 .567 & 2.036 .706 .290 .000 & $278.946 .783 .365,23$ & $537.212 .219 .926,49$ \\
LEV & 16,00 & 356,00 & 100,97 & 92,26 \\
MOWN & 0,0004 & 65,02 & 8,63 & 19,21 \\
\hline
\end{tabular}




\begin{tabular}{ccccc}
\hline INST & 10,10000 & 97,82 & 65,39 & 23,69 \\
$\boldsymbol{C S R}$ & 13,92 & 100,00 & 42,61 & 25,54 \\
\hline
\end{tabular}

Berdasarkan tabel 1 disajikan nilai rata-rata nilai perusahaan dari 44 objek pengamatan sebesar 1,94 lebih besar dari standar deviasi sebesar 1,27 yang menunjukan bahwa data nilai perusahaan yang diproksikan dengan Tobin's $Q$ telah terdistribusi dengan baik. Nilai minimum nilai perusahaan sebesar 0,73 dimiliki oleh PT Energi Mega Persada, Tbk. Hal tersebut menunjukkan bahwa PT Energi Mega Persada, Tbk memiliki nilai perusahaan yang paling rendah. Sedangkan untuk nilai maksimum sebesar 6,92 yang dimiliki oleh PT Resource Alam Indonesia, Tbk. Hal tersebut menunjukkan bahwa PT Resource Alam Indonesia, Tbk memiliki nilai perusahaan paling tinggi.

Menurut Herawaty (2008) perusahaan yang memiliki Tobin's Q dengan nilai yang semakin tinggi menunjukkan bahwa prospek pertumbuhan perusahaan semakin baik, karena investor akan mengeluarkan pengorbanan yang lebih untuk perusahaan yang memiliki nilai pasar aset yang lebih besar daripada nilai bukunya. Sari dan Riduwan (2013) dalam penelitiannya menyatakan jika rasio-Q di atas satu, ini menunjukkan bahwa investasi dalam aset menghasilkan laba yang memberikan nilai yang lebih tinggi daripada pengeluaran investasi, hal ini akan merangsang investasi baru. Dan jika rasio-Q di bawah satu, investasi dalam aset tidaklah menarik.

Nilai rata-rata capital expenditure dari 44 objek pengamatan lebih kecil dari standar deviasi. Hal ini menunjukan bahwa kemungkinan data capital expenditure tidak terdistribusi dengan baik. Nilai minimum capital expenditure yang dimiliki oleh PT Bayan Resources, Tbk. Menunjukkan bahwa PT Bayan Resources, Tbk mengalami penurunan pengeluaran modal yang paling besar dibandingkan dengan perusahaan lain. Sedangkan untuk nilai maksimum oleh PT Aneka Tambang (Persero), menunjukkan perusahaan tersebut mengalami kenaikan pengeluaran modal yang paling tinggi dibandingkan dengan perusahaan lain.

Nilai rata-rata leverage dari 44 objek pengamatan sebesar 100,98 yang lebih besar dari standar deviasi sebesar 92,26 yang menunjukkan bahwa data leverage telah terdistribusi dengan baik. Nilai minimum leverage sebesar 16 dimiliki oleh PT Energi Mega Persada, Tbk. Hal tersebut menunjukkan bahwa PT Energi Mega Persada, Tbk memiliki tingkat rasio hutang atau leverage yang paling rendah. Sedangkan untuk nilai maksimum sebesar 356,00 dimiliki oleh PT Citatah, Tbk. Hal tersebut menunjukkan bahwa PT Citatah, Tbk memiliki tingkat leverage paling tinggi.

Nilai rata-rata kepemilikan manajerial dari 44 objek pengamatan sebesar 8,6304 lebih kecil dari standar deviasi sebesar 19,21 yang menunjukan bahwa terjadi kemungkinan data kepemilikan manajerial tidak berdistribusi baik. Nilai minimum kepemilikan manajerial sebesar 0,00 dimiliki oleh PT Timah (Persero), Tbk. Hal tersebut menunjukkan bahwa PT Timah (Persero), Tbk memiliki kepemilikan manajerial yang paling rendah. Nilai tersebut bukan berarti PT Timah (Persero), Tbk tidak memiliki kepemilikan manajerial, tetapi proporsi saham yang dimiliki manajerial 
sangat rendah pada tahun 2011 yaitu sebesar 0,00040 persen. Sedangkan untuk nilai maksimum sebesar 65,02 yang dimiliki oleh PT Bayan Resources Tbk. Hal tersebut menunjukkan bahwa PT Bayan Resources, Tbk memiliki kepemilikan manajerial paling tinggi.

Nilai rata-rata kepemilikan institusional dari 44 objek pengamatan sebesar 65,39 lebih besar dari standar deviasi sebesar 23,97 yang menunjukan bahwa data kepemilikan intitusional telah terdistribusi dengan baik. Nilai minimum kepemilikan institusional sebesar 10,10 yang dimiliki oleh PT Atlas Resources,Tbk. Hal tersebut menunjukkan bahwa PT Atlas Resources, Tbk. memiliki kepemilikan institusional yang paling rendah. Sedangkan untuk nilai maksimum sebesar 97,82 yang dimiliki oleh PT Tambang Batubara Bukit Asam (Persero), Tbk. Hal tersebut menunjukkan bahwa PT Tambang Batubara Bukit Asam (Persero), Tbk memiliki kepemilikan institusional paling tinggi.

Nilai rata-rata $C S R$ dari 44 objek pengamatan sebesar 42,61 lebih besar dari standar deviasi sebesar 25,54 yang menunjukan bahwa data CSR telah terdistribusi dengan baik. Nilai minimum CSR sebesar 13,92 yang dimiliki oleh PT Mitra Investindo, Tbk. Sedangkan untuk nilai maksimum sebesar 100, dimiliki oleh beberapa perusahaan yang mengungkapkan seluruh kriteria pengungkapan $C S R$ berdasarkan GRI-G3, salah satunya PT Aneka Tambang (Persero), Tbk.

Hasil pengujian menggunakan regresi linear berganda pada tabel 2 menunjukkan hasil Uji F (uji simultan), nilai F hitung sebesar 2,560 dengan nilai sig $0,05 \leq 0,05$ sehingga dapat disimpulkan bahwa variabel leverage, kepemilikan manajerial, kepemilikan institusional, dan CSR berpengaruh secara bersama-sama terhadap nilai perusahaan.

Tabel 2

Hasil Uji Statistik Uji t

\begin{tabular}{cccll}
\hline Model & B & t & Sig. & \multicolumn{1}{c}{ Keterangan } \\
\hline Constant & 2,32 & 2,97 & 0,01 & \\
X2 & $-0,01$ & $-2,6$ & 0,01 & Berpengaruh negatif \\
X3 & 0,03 & 2,49 & 0,02 & Berpengaruh positif \\
X4 & 0,01 & 0,64 & 0,53 & Tidak berpengaruh \\
X5 & $-0,01$ & $-1,14$ & 0,26 & Tidak berpengaruh \\
& Uji F & & 0,05 & Berpengaruh \\
& Adjusted $\mathbf{R}^{\mathbf{2}}$ & & 0,13 & \\
\hline
\end{tabular}

Hasil Uji t (uji parsial) pada tabel 2 menunjukkan hasil dari leverage terhadap nilai perusahaan memiliki nilai koefisien sebesar -0,01 dan tingkat signifikasi 0,01 $<$ 0,05). Berdasarkan hasil tersebut leverage berpengaruh negatif terhadap nilai perusahaan. Kepemilikan manajerial terhadap nilai perusahaan memiliki nilai koefisien sebesar 0,03 dan tingkat signifikansi 0,02 $(<0,05)$. Berdasarkan hasil tersebut kepemilikan manajerial berpengaruh positif terhadap nilai perusahaan. Kepemilikan institusional terhadap nilai perusahaan memiliki nilai koefisien sebesar 0,007 dan tingkat signifikansi 0,53 (> 0,05). Berdasarkan hasil tersebut kepemilikan institusional tidak berpengaruh terhadap nilai perusahaan. Corporate Social Responsibility terhadap 
nilai perusahaan memiliki nilai koefisien sebesar $-0,01$ dan tingkat sig. 0,26 0,05. Berdasarkan hasil tersebut CSR tidak berpengaruh terhadap nilai perusahaan.

Koefisien determinasi $\left(\mathrm{R}^{2}\right)$ memiliki nilai sebesar 0,13. Hal tersebut menunjukkan bahwa variabel nilai perusahaan dipengaruhi sebesar 13 persen oleh leverage, kepemilikan manajerial, kepemilikan institusional, dan CSR. Sisanya yaitu sebesar 87,1 persen dijelaskan oleh variabel lain di luar variabel penelitian, seperti profitabilitas, ukuran perusahaan, kebijakan dividen, dan lain sebagainya.

\section{Pengaruh Leverage terhadap Nilai Perusahaan}

Hasil penelitian ini menunjukkan bahwa leverage berpengaruh negatif terhadap nilai perusahaan. Hasil ini tidak sesuai dengan hipotesis penelitian. Hasil tersebut sesuai dengan penelitian Mahendra et al. (2012) dan Nguyen (2015) yang menyatakan bahwa leverage berpengaruh negatif terhadap nilai perusahaan.

Jika Debt to Equity Ratio tinggi, maka perusahaan memiliki resiko yang tinggi untuk tidak memberikan return maksimal kepada shareholder. Tingginya rasio DER menunjukan semakin banyaknya hutang dari pada total aset yang dimiliki oleh perusahaan. Hal tersebut membuat suatu risiko yang tinggi karena perusahaan tidak memiliki kemampuan untuk membayar hutang yang mencukupi. Ketika perusahaan memiliki resiko membayar hutang yang tidak mencukupi, perusahaan akan berisiko memberikan return yang kurang maksimal kepada shareholder, sehingga shareholder akan memberikan penilaian negatif. Penilaian negatif tersebut akan membuat harga saham turun, diikuti dengan penurunan nilai perusahaan (Yuliana dan Juniarti 2015).

Hasil dari penelitian ini sesuai dengan teori trade-off yang menyatakan bahwa hubungan struktur modal dan nilai perusahaan dapat bersifat non-linear. Dimana ketika perusahaan berada pada tingkat hutang dibawah titik optimum, maka setiap peningkatan hutang akan meningkatkan nilai perusahaan dikarenakan perolehan manfaat pajak dari bunga (tax saving). Namun, ketika hutang terus meningkat hingga melebihi titik optimumnya, maka akan timbul kesulitan keuangan dan memicu terjadinya agency cost of debt serta resiko kebangkrutan. Risiko biaya kebangkrutan dan agency cost of debt yang porsinya melebihi manfaat pajak yang diperoleh perusahaan dari penggunaan hutang dapat menurunkan nilai perusahaan. Penjelasan tersebut sesuai dengan sampel penelitian, yaitu terdapat beberapa perusahaan pada sampel penelitian yang telah mencapai atau bahkan melebihi titik optimum penggunaan hutangnya, dimana ketika tingkat hutang telah melebihi titik optimum nya sehingga nilai perusahaan akan menurun. Hal ini dapat dilihat dari data penelitian yang menunjukkan bahwa terdapat beberapa perusahaan yang jumlah hutang nya melebihi jumlah ekuitasnya, contohnya saja pada perusahaan PT Atlas Resources Tbk; PT Bayan Resources Tbk; PT Energi Mega Persada Tbk; dan PT Citatah Tbk.

\section{Pengaruh Kepemilikan Manajerial terhadap Nilai Perusahaan}


Kepemilikan manajerial dalam teori keagenan merupakan salah satu cara yang dapat dilakukan perusahaan dalam usaha mengurangi agency conflict. Adanya kepemilikan saham manajerial dipandang dapat menyelaraskan potensi perbedaan kepentingan antara pihak manajemen dengan pemegang saham, sehingga dengan begitu permasalahan keagenan diasumsikan akan hilang apabila seorang manajer adalah juga sekaligus sebagai seorang pemilik. Semakin besar proporsi kepemilikan manajemen pada perusahaan, maka manajemen cenderung lebih giat untuk memenuhi kepentingan pemegang saham yang notabene adalah dirinya sendiri (Sari dan Riduwan 2013).

Hasil penelitian ini menyatakan bahwa kepemilikan manajerial memiliki pengaruh positif signfikan terhadap nilai perusahaan. Hal ini sejalan dengan penjelasan diatas dan sesuai dengan hipotesis penelitian. Hasil tersebut didukung oleh penelitian dari Rizqia et al. (2013), Susanto dan Subekti (2013), dan Saputra (2010). Kepemilikan manajerial membuat para manajer akan berusaha untuk meningkatkan nilai kekayaannya sebagai pemegang saham perusahaan, yang akhirnya juga akan meningkatkan nilai perusahaan. Dengan demikian, kepemilikan manajerial mampu menjadi mekanisme untuk meningkatkan nilai perusahaan.

\section{Pengaruh Kepemilikan Institusional terhadap Nilai Perusahaan}

Kepemilikan institusional dipandang dapat mengurangi konflik keagenan karena mampu mengontrol dan mengarahkan manajer untuk membuat kebijakan hutang dan deviden yang berpihak pada kepentingan pemegang saham institusional (Haryono et al., 2015). Namun hasil penelitian menyatakan bahwa kepemilikan institusional tidak memiliki pengaruh yang signifikan terhadap nilai perusahaan. Hasil ini tidak sesuai dengan penjelasan diatas serta hipotesis penelitian yang menyatakan bahwa kepemilikan institusional dan nilai perusahaan memiliki hubungan positif signifikan. Hasil tersebut konsisten dengan penelitian yang dilakukan oleh Rachman dan Maghviroh (2011), Siek dan Murhadi (2015), serta Saputra (2010). Hal ini bisa saja terjadi dikarenakan adanya informasi asimetris yang timbul antara pemilik institusi dengan manajemen perusahaan sehingga tindakan yang dilakukan oleh manajemen perusahaan belum tentu sepenuhnya dimiliki oleh investor institusional.

Jumlah pemegang saham yang besar juga tidak efektif dalam memonitor perilaku manajer dalam perusahaan (Demsetz dan Villalonga 2001). Thomsen et al. 2006 menyatakan bahwa ketika konsentrasi kepemilikan cenderung tinggi (mayoritas), maka perlindungan terhadap pemegang saham lainnya akan semakin rendah, dan pemilik institusional memiliki motivasi dan tujuan lain selain dari nilai perusahaan. Karena itulah kepemilikan institusional bisa saja tidak dapat mempengaruhi nilai perusahaan.

Selain itu, tidak adanya pengaruh akan investor institusi terhadap nilai perusahaan juga dapat disebabkan oleh kualitas dari investor institusi itu sendiri. Jika kualitas dari institusi tersebut tidak bagus, maka pengawasan yang diharapkan tentu 
tidak dapat terpenuhi seutuhnya sehingga hal tersebut tidak dapat mempengaruhi nilai perusahaan. Misalnya saja institusi asing. Kebanyakan institusi asing mungkin hanya melakukan pengawasan yang sekedarnya dikarenakan banyaknya kendala dan keterbatasan. Pernyataan tersebut pun sesuai dengan data penelitian. Contohnya, perusahaan MITI di tahun 2014 memiliki presentase pemilik institusi sebesar 75 persen yang terdiri dari 0,01 persen dana pensiun; 0,12 persen broker; 5,97 persen perusahaan terbatas NPWP, 1,20 persen perusahaan asuransi, dan yang paling banyak yaitu institusi asing sebesar 68,08 persen. Begitupun dengan perusahaan KKGI di tahun 2013 perusahaan asing memegang kepemilikan sebesar 78,30 persen dari total 83 persen pemilik instutisi pada perusahaan tersebut. Hal tersebut pun terjadi pada beberapa perusahaan lain, seperti PT Citatah, Tbk dan PT Energi Mega Persada, Tbk.

\section{Pengaruh Corporate Social Responsibility terhadap Nilai Perusahaan}

Corporate Social Responsibility merupakan salah satu faktor non-keuangan yang sekarang ini perlu dipertimbangkan oleh perusahaan dalam upaya meningkatkan nilai perusahaan (Susanto dan Subekti 2013). Semakin banyak bentuk pertanggungjawaban yang dilakukan perusahaan terhadap lingkungannya, image perusahaan menjadi meningkat. Berdasarkan hasil penelitian ini, diketahui bahwa $C S R$ tidak memiliki pengaruh yang signifikan terhadap nilai perusahaan. Hasil penelitian ini sejalan dengan penelitian yang dilakukan oleh Susanto dan Subekti (2013), Yuliana dan Juniarti (2015), Agustine (2014), serta Tjia dan Setiawati (2012), namun tidak sesuai dengan hipotesis penelitian yaitu $C S R$ berpengaruh positif terhadap nilai perusahaan.

Hal tersebut bisa dikarenakan para investor yang tidak memperhatikan resiko sosial perusahaan yang dapat terhindar akibat dari adanya CSR. CSR sendiri merupakan program sosial perusahaan yang dilakukan dengan melibatkan masyarakat sekitar yang menimbulkan hubungan timbal balik antara perusahaan dengan masyarakat, dimana perusahaan dapat membantu masyarakat baik dalam hal ekonomi, lingkungan, maupun pendidikan, dan masyarakat dapat turut membantu serta melancarkan keberlangsungan hidup perusahaan dalam berbagai hal. Sehingga apabila tidak ada $C S R$, maka perusahaan terancam akan menghadapi risiko sosial, seperti konspirasi, demo masyarakat sekitar, dan lain sebagainya yang tentunya akan menghambat produktivitas perusahaan. Sedangkan apabila perusahaan melakukan $C S R$, maka perusahaan akan terhindar dari risiko-risiko tersebut. Berdasarkan hasil penelitian, banyak investor yang kurang memperhatikan hal ini. Hal tersebut mungkin terjadi dikarenakan tidak adanya hubungan langsung antara investor dengan masyarakat sekitar sehingga mereka sedikit mengabaikan mengenai risiko sosial perusahaan.

\section{SIMPULAN, KETERBATASAN DAN SARAN}


Berdasarkan analisis data dan pembahasan, dapat diperoleh kesimpulan sebagai berikut: (1) capital expenditure tidak lolos uji asumsi klasik sehingga harus dikeluarkan dari variabel penelitian, (2) leverage berpengaruh negatif signifikan terhadap nilai perusahaan, (3) kepemilikan manajerial berpengaruh positif signifikan terhadap nilai perusahaan, (4) kepemilikan institusional tidak berpengaruh terhadap nilai perusahaan, (5) CSR tidak berpengaruh terhadap nilai perusahaan.

Keterbatasan penelitian adalah adjusted $R$ Square pada penelitian ini cukup rendah, yaitu hanya sebesar 13 persen. Artinya, nilai perusahaan dipengaruhi sebesar 87,1 persen oleh variabel lain diluar variabel penelitian. Oleh karena itu, penelitian selanjutnya disarankan untuk menggunakan variabel bebas lainnya selain variabel penelitian, misalnya kebijakan dividen, profitabilitas, ukuran perusahaan, dan sebagainya. Selain itu, peneliti selanjutnya dapat menambah variabel $G C G$ lainnya selain kepemilikan manajerial dan kepemilikan institusional, misalnya komisaris independen, board size, komite audit, dan lain lain.

Perusahaan pun disarankan untuk terus memperhatikan proporsi leverage serta kepemilikan manajerial agar selalu pada posisi optimalnya sehingga hal tersebut dapat memunculkan sinyal positif bagi para investor dan kemudian akan meningkatkan permintaan saham perusahaan. Sedangkan investor sebaiknya memperhatikan tingkat leverage serta proporsi kepemilikan manajerial perusahaan sebelum memutuskan untuk berinvestasi. Hal ini dikarenakan kedua faktor tersebut merupakan faktor-faktor yang dapat mempengaruhi nilai perusahaan, hal itu dapat mencerminkan kinerja perusahaan yang baik.

\section{DAFTAR PUSTAKA}

Achmad, S. L., dan L. Amanah. 2014. "Pengaruh keputusan investasi, keputusan pendanaan, kebijakan deviden dan kinerja keuangan terhadap nilai perusahaan". Jurnal Ilmu dan Riset Akuntansi 3(9): 1-15.

Agustina, S. 2013. "Pengaruh profitabilitas dan pengungkapan corporate social responsibility terhadap nilai perusahaan (Studi empiris pada perusahaan manufaktur yang terdaftar di Bursa Efek Indonesia)". E-Journal Universitas Negeri Padang. Diakses 23 Desember 2016.

Agustine, I.. 2014. "Pengaruh corporate social responsibility terhadap nilai perusahaan". Finesta 2(1): 42-47.

Amri, C., dan Untara. 2010. "Analisis pengaruh kinerja keuangan, good corporate governance dan corporate social responsibility terhadap nilai perusahaan". EJournal Universitas Gunadarma. Diakses 23 Desember 2016. Tersedia di http://publication.gunadarma.ac.id/bitstream/123456789/981/1/21207473.pdf

Bidhari, S. C., U. Salim, dan S. Aisjah. 2013. "Effect of corporate social responsibility information disclosure on financial performance and firm value in banking 
industry listed at Indonesia Stock Exchange". European Journal of Business and Management 5(18): 39-47.

Brealey, R. A., S. C. Myers, dan A. J. Marcus, 2007. "Dasar-dasar manajemen keuangan perusahaan”. Jakarta: Penerbit Erlangga.

Brigham dan Houston. 2006. "Fundamentals of financial management". Edisi ke Sepuluh, Jakarta: Salemba Empat.

Carter, W. K., dan M. F. Usry. 2002. “Akuntansi biaya”. Edisi ke Tiga Belas, Jakarta: Salemba Empat.

Demsetz, H., dan B. Villalonga. 2001. Ownership structure and corporate performance. Journal of Finance 7: 209-233.

Diyah, P., dan E. Widanar. 2009. "Pengaruh struktur kepemilikan terhadap nilai perusahaan: Keputusan keuangan sebagai variabel intervening”. Jurnal Ekonomi Bisnis dan Akuntansi Ventura 12(1): 71-86.

Elmasr, H. 2007. "Capital intensity and stock returns". Journal of Investment Strategy 2(1): 61-66.

Fahadayna, A. C. 2011. "Krisis finansial Eropa 2011: Penyebab dan dampaknya kepada Euro zone dan Indonesia”. Working paper. Diakses 23 Desember 2016. Tersedia http://www.academia.edu/19669714/Krisis_Finansial_Eropa_2011_Penyebab _dan_Dampaknya_kepada_Euro_Zone_dan_Indonesia

Ghozali, I. 2013. “Aplikasi analisis multivariate dengan program IBM SPSS 20”. Semarang: Badan Penerbit Universitas Diponegoro.

Griner, E. H., dan L. A. Gordon. 1995. "Internal cash flow, insider ownership and capital expenditure: A test of pecking order and managerial hypotheses". Journal of Business Finance and Accounting 22(2): 179-199.

Hadi, N. 2011. “Corporate social responsibility”. Yogyakarta: Graha Ilmu.

Hamidi, M. 2003. "Internal cash flows, insider ownership, investment opportunity dan capital expenditures: Suatu pengujian terhadap hipotesis pecking order dan managerial". Jurnal Ekonomi dan Bisnis Indonesia 18(3): 271-287.

Haruman, T. 2008. "Pengaruh struktur kepemilikan terhadap keputusan keuangan dan nilai perusahaan”. Simposium Nasional Akuntansi XI. Pontianak.

Haryono, S. A., Fitriany, dan E. Fatimah. 2015. "Analisis pengaruh struktur modal dan struktur kepemilikan terhadap nilai perusahaan". Simposium Nasional Akuntansi XVIII. Medan.

Herawaty, V. 2008. "Peran praktek corporate governance sebagai moderating variable dari pengaruh earnings management terhadap nilai perusahaan”. Jurnal Akuntansi Dan Keuangan 10(2) : 97-108. 
Hermuningsih, S. 2013. "Pengaruh profitabilitas, growth opportunity, struktur modal terhadap nilai perusahaan pada perusahaan publik di Indonesia". Buletin Ekonomi Moneter dan Perbankan (Oktober): 127-148.

Jensen, M., dan W. Meckling. 1976. "Theory of the firm: managerial behavior, agency costs and ownership structure”. Journal of Financial Economics 3: 305-60.

Kusumajaya, D. K. O. 2011. "Pengaruh struktur modal dan pertumbuhan perusahaan terhadap profitabilitas dan nilai perusahaan pada perusahaan manufaktur di Bursa Efek Indonesia”. Tesis. Universitas Udayana Denpasar Bali.

Lindenberg, E., dan S. Ross. 1981. "Tobin's q ratio and industrial organization". Journal of Business 54(1): 1-32.

Mahendra, A. D., L. G. S. Artini, dan A. A. G. Suarjaya. 2012. "Pengaruh kinerja keuangan terhadap nilai perusahaan pada perusahaan manufaktur di Bursa Efek Indonesia". Jurnal Manajemen, Strategi Bisnis, dan Kewirausahaan 6(2): 130138.

Mardiasmo. 2009. “Akuntansi sektor publik”. Yogyakarta : Andi

McWilliams, A., dan D. S. Siegel. 2000. "Corporate social responsibility and financial performance: Correlation or misspecification?". Strategic Management Journal 21(5): 603-609.

Myers, S. 1977. "Determinants of corporate borrowing”. Journal Financial Economics 5: $147-175$.

Nguyen, N. 2015. "Does hedging increase firm value? An examination of Swedish companies". Thesis. Master Programme in Finance Lund University.

Ogolmagai, N. 2013. "Leverage pengaruhnya terhadap nilai perusahaan pada industri manufaktur yang go public di Indonesia”. Jurnal EMBA 1(3): 81-89.

O'Donovan, G. 2002. "Environmental disclosures in the annual report: Extending the applicability and predictive power of legitimacy theory". Accounting, Auditing and Accountability 15(3): 344 - 371.

Pertiwi, T. K., dan F. M. I Pratama. 2012. "Pengaruh kinerja keuangan, good corporate governance terhadap nilai perusahaan food and beverage". Jurnal Manajemen Dan Kewirausahaan 14(2): 118-127.

Rachman, A. A., dan R. ElMaghviroh. 2011. "Pengaruh corporate social responsibility (CSR), kepemilikan manajerial dan institusional terhadap nilai perusahaan". EJournal STIE Perbanas. Diakses 23 Desember 2016. Tersedia di http://eprints.perbanas.ac.id/1826/1/ARTIKEL\%20ILMIAH.pdf

Rizqia, D. A., S. Aisjah, dan Sumiati. 2013. "Effect of managerial ownership, financial leverage, profitability, firm size, and investment opportunity on dividend 
policy and firm value". Research Journal of Finance and Accounting 4(11): 120-130.

Rosiana, G. A. M. E., G. Juliarsa, dan M. M. R. Sari. 2013. "Pengaruh pengungkapan CSR terhadap nilai perusahaan dengan profitabilitas sebagai variabel pemoderasi”. E-Jurnal Akuntansi Universitas Udayana 5(3): 723-738.

Saputra, M. 2010. "Pengaruh corporate governance terhadap nilai perusahaan di Bursa Efek Indonesia Jakarta”. Journal of Indonesian Applied Economics 4(1): 8192.

Saraswati, R., dan B. Hadiprajitno. 2012. "Pengaruh corporate governance pada hubungan corporate social responsibility dan nilai perusahaan manufaktur yang terdaftar BEI”. Jurnal Akuntansi \& Auditing 9(1).

Sari, E. F. V., dan A. Riduwan. 2013. "Pengaruh corporate governance terhadap nilai perusahaan: Kualitas laba sebagai variabel intervening". Jurnal Ilmu dan Riset Akuntansi 1(1): 1-20.

Sartono, A. 2001. "Pengaruh aliran kas internal dan kepemilikan manajer dalam perusahaan terhadap pembelanjaan modal: Managerial hypotheses atau pecking order hypotheses?”. Jurnal Ekonomi dan Bisnis Indonesia 16(1): 5463.

Sayekti, Y., dan S. W. Lodovicus. 2007. "Pengaruh CSR disclosure terhadap earning response coefficient (Suatu studi empiris pada perusahaan yang terdaftar di Bursa Efek Jakarta)”. Simposium Nasional Akuntansi X. Makassar.

Sembiring, E. R. 2003. "Kinerja keuangan, political visibility, ketergantungan pada hutang dan pengungkapan tanggung jawab sosial perusahaan". Simposium Nasional Akuntansi VI. Surabaya.

Septianingrum, T. 2014. "Pengaruh penerapan mekanisme corporate governance dan pengungkapan corporate social responsibility terhadap nilai perusahaan". $E$ Journal Akuntansi UDINUS. Diakses 23 Desember 2016. Tersedia di http://eprints.dinus.ac.id/17116/1/jurnal_15475.pdf

Siek, R. W., dan R. M. Werner. 2015. "Studi pengaruh tata kelola perusahaan terhadap nilai perusahaan”. Jurnal Ilmiah Mahasiswa Universitas Surabaya. 4(2): 1-32.

Sisharini, N. K. 2013. "Analisis pengaruh tingkat kesehatan bank dan faktor fundamental makro ekonomi terhadap nilai perusahaan pada perusahaan perbankan yang tercatat di Bursa Efek Indonesia”. Disertasi. Universitas Negeri Malang.

Sucipto, A. 2015. "Ekonomi lesu, 125 perusahaan batu bara bangkrut, 5.000 orang kena PHK”. Kompas.com. 12 Agustus 2015. Diakses 21 Januari 2017. Tersedia di 
http://ekonomi.kompas.com/read/2015/08/12/060100026/Ekonomi.Lesu.125. Perusahaan.Batu.Bara.Bangkrut.5.000.Orang.Kena.PHK

Sudiyatno, B., dan E. Puspitasari. 2010. “Tobin's Q dan Altman Z-Score sebagai indikator pengukuran kinerja". Kajian Akuntansi 2(1) : 9-21.

Sudiyatno, B., E. Puspitasari, dan A. Kartika, 2012. "The company's policy, firm performance, and firm value: An empirical research on Indonesia Stock Exchange". American International Journal of Contemporary Research 2(12): $30-40$.

Sukamulja, S. 2004. "Good corporate governance di sektor keuangan: Dampak GCG terhadap kinerja perusahaan (Kasus di Bursa Efek Jakarta)”. BENEFIT 8(1): 125.

Susanto, I., A. Taman, dan Sukirno. 2004. "Balanced scorecard sebagai alat pengukuran kinerja manajemen (Studi kasus pada PT Sari Husada)". Jurnal Pendidikan Akuntansi Indonesia 3(1): 40-50.

Susanto, P. B., dan I. Subekti. 2013. "Pengaruh corporate social responsibility dan good corporate governance terhadap nilai perusahaan (Pada perusahaan yang terdaftar Di Bursa Efek Indonesia)". Jurnal Ilmiah Mahasiswa Universitas Brawijaya 1(2).

Tarjo. 2008. "Pengaruh konsentrasi kepemilikan institusional dan leverage terhadap manajemen laba, nilai pemegang saham serta cost of equity capital". Simposium Nasional Akuntansi XI. Pontianak.

Thomsen, S., T. Pedersen, dan H. K. Kvist. 2006. "Blockholder ownership: Effects on firm value in market and control based governance systems". Journal of Corporate Finance 12: 246-269.

Tjia, O., dan L. Setiawati. 2012. "Effect of CSR disclosure to value of the firm: Study for banking industry in Indonesia”. World Journal of Social Sciences 2(6): 169178.

Yuliana, O., dan Juniarti. 2015. "Pengaruh corporate social responsibility terhadap nilai perusahaan di Indonesia yang bergerak di sub sektor retail dan trade, healthy care, computer dan service, dan investment company". Business Accounting Review 3(2): 151-160. 
Volume 20 No. 2, Oktober 2017

ISSN 1979 - 6471 
